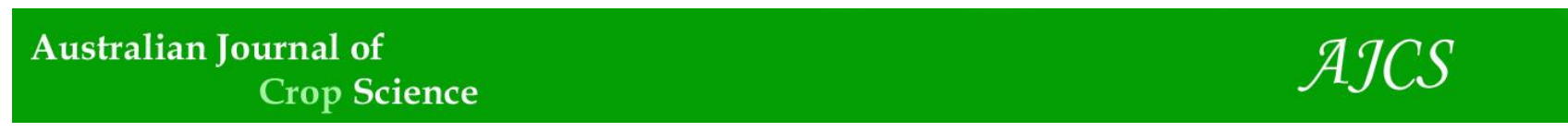

AJCS 14(02):286-294 (2020)

ISSN:1835-2707

doi: 10.21475/ajcs.20.14.02.p2183

\title{
Use of aerial image in the estimation of volume and biomass of Eucalyptus sp. forest stand
}

\author{
Thallita R. S. Mendes, Eder P. Miguel*, Pedro G. A. Vasconcelos, Marco B. X. Valadão, Alba V. Rezende, \\ Eraldo A. T. Matricardi, Humberto Angelo, Alcides Gatto, Mauro E. Nappo
}

Department of Forestry Engineering, University of Brasilia (UnB), DF, Brazil

*Corresponding author: pedroguilherme.av@gmail.com

\begin{abstract}
Assessing forest stands is crucial for managing and planning the use of these resources. Forest inventory is the instrument that provides information about the stand situation, which can be costly and time consuming. In order to facilitate and reduce the time spent obtaining these data, the main objective of this work was to evaluate the accuracy of volume and biomass estimates per unit area with data from remote sensing. Forty sample units were allocated and georeferenced, in which all trees with diameter at breast height $(\mathrm{DBH}) \geq 5 \mathrm{~cm}$ were inventoried. Sequentially, the cubage was performed in order to obtain individual biomass, volume, and adjustment of the individual models. With data from georeferenced images of the study area, the vegetation indices MSAVI (Modified Soil-Adjusted Vegetation Index) and NDVI (Normalized Difference Vegetation Index) were obtained. The volume and biomass estimation using remote sensing variables were carried out through the adjustment of sigmoidal models by regression analysis, which used a combination of the average values of the vegetation indices and the basal area of the plot/hectares as an independent variable. The fit statistics and the accuracy of the tested models presented consistent results to estimate forest production. The results showwd that indices derived from remote sensing techniques associated with forest variables information could accurately estimate the volume and biomass of Eucalyptus spp. plantations.
\end{abstract}

Keywords: vegetation indices, forest stands, biomass.

Abbreviations: DBH_diameter at breast height, MSAVI_Modified Soil-Adjusted Vegetation Index, NDVI_Normalized Difference Vegetation Index.

\section{Introduction}

The genus Eucalyptus spp. has rapid growth, extensive distribution and meets the demands of a wide range of markets (Ferraz Filho et al., 2014; Fumes et al., 2017; Hernández-Ramos et al., 2017). The selection of the species depends mainly on the climate and the physical and chemical characteristics of the soil, as well as the destination of the wood produced (Gonçalves et al., 2017; Marcatti et al., 2017).

In addition to productivity, forest plantations have great potential to store carbon through the production of biomass (Pan et al., 2013; Fontoura et al., 2017). Different types of forests store different amounts of carbon in terms of their succession stage, yield, age, management regime and species composition (Ribeiro et al., 2015; Du et al., 2015).

Traditionally the quantification of biomass and volume of wood is realized through forest inventories. In general, the realization of a forest inventory is a very laborious, timeconsuming process and sometimes some remote areas are difficult to reach (Timothy et al., 2016). Understanding biophysical parameters of forests such as volume and biomass are the main purpose of forest inventories. This includes critical information about the spatial and temporal distribution of forests (Miura et al., 2010).

Contemporary forest management in forest stands or native forests requires spatially continuous and multitemporal information retrieval with comparable scenarios, providing a basis for the successful implementation of sustainable and continuous long-term tree management (Pasher and King, 2010, Huang et al., 2018).

In the last decades, remote sensing has played a crucial role in forest monitoring and management, disaster management and agricultural applications (White et al., 2016; Mendes et al., 2018), providing an alternative that is low cost, environmentally friendly and fast to monitoring the vegetation (Zhang et al., 2018; Vrieling et al., 2018).

Remote sensing includes techniques that use satellite images, allows the observation of the area of interest as a whole. In a consistent way, repetitive systematic of the forest growth, allows characterization and differences of growth and productivity of the area. (Ponzini et al., 2015; Huang et al., 2018). In this scenario, its use offers new possibilities: it broadens the reach to the areas, helps and improves the estimates obtained in the field (Leyk et al., 2002; Oliveira et al., 2014) and makes the process of obtaining data easier and less onerous (Miguel et al., 2015). The use of satellite images for the forestry and agriculture areas requires sufficient spatial and temporal resolutions to enable in-field monitoring (Kross et al., 2015).

For the management and feasible quantification of forest resources, promotion of strategies to be used in decision 
making is vital. To employ remote sensing techniques, it is necessary that the data obtained be able to predict parameters such as volume of way and population density of (Günlü et al., 2012).

It is important to promote the development of new techniques to integrate field and remote sensing data. This will improve efficiency of estimation of biophysical parameters of forest stands, while at the same time shortens the time of surveys. Therefore, with the need to optimize the estimates of dendrometric variables for forest stand growth and production in a faster and more efficient way, this study aimed to adjust and select equations to integrate remote sensing data with field information. This will help consistent estimations of volume and biomass from Eucalyptus spp. plantations.

\section{Results and discussion}

Adjustment and selection of mathematical models for estimating the volume and biomass of individual trees

For volume estimation, three models presented adjusted coefficients of determination (adjusted $R^{2}$ ) higher than 0.99 and standard errors of the estimate in percentage (Syx\%) less than 6\% (Table 1). The Schumacher and Hall model presented the lowest absolute and relative errors and higher $R^{2}$, corroborates as one of the widely diffused models. The results of Syx\% are compatible with the results found by Pelissari et al., (2011), Hernández-Ramos et al. (2017), and Tewari and Singh (2018).

The Figure 1 shows the dispersion of estimated value by observed value, the dispersion of residuals and the distribution in error classes obtained for the adjustments of equations for volume estimation.

For the estimation of biomass, the three models presented satisfactory values for the adjusted $R^{2}$ and Syx\% (Table 1). However, there is a slight loss of precision when compared with the statistics of volume. This is an expected result, since in the biomass estimation there was an additional independent variable which was density. For the biomass adjustment the Schumacher-Hall model resulted in better statistics.

As can be seen in Figure 2c, the dispersion error classes of Schumacher-Hall model has the tendency to overestimate the biomass variable.

The " $\mathrm{t}$ " test for paired means showed that the adjusted Schumacher-Hall model was efficient and significant in the estimation of volume and biomass. Therefore, there was no significant difference between the estimated and observed variables, a conclusion obtained from the "P" values obtained for all models, when compared considering a level of significance of $5 \%$, according to Table 2 .

The Schumacher and Hall model is widely used in the forestry sector, since in most adjustment cases (volume and biomass) it presents satisfactory estimates with low errors. This fact was verified in the present study. The choice of this model is in agreement with that obtained by Cecilia et al. (2014), Santana et al. (2017), Freitas and Andrade (2017) and Santiago-García et al. (2017)

\section{Forest inventory}

After selecting the best adjusted equations, the individual volumes and biomasses of all the trees were estimated in their respective plots and, subsequently, these values were extrapolated per hectare.

The coefficient of variation (CV\%) of both estimated variables (volume and biomass) were around $17 \%$, which indicates a moderate stocking heterogeneity (Gomes and Garcia, 2002). The CV\% makes inference of dispersion around of the average, although it is in a dimensionless scale.

The volume of wood had an average of $330.35 \mathrm{~m}^{3} / \mathrm{ha}$, standard deviation of $57.35 \mathrm{~m}^{3} /$ ha absolute sampling error of $17.19 \mathrm{~m}^{3} / \mathrm{ha}$, when analyzed in percentage $5.20 \%$. These mean values of volume production for eucalyptus stands are within the standard observed in other studies in Brazil, where the volume per hectare is between 245 and $385 \mathrm{~m}^{3} /$ ha (Castro et al., 2013; Oliveira et al., 2014; Souza et al., 2017).

The average biomass value was $173.41 \mathrm{t} / \mathrm{ha}$, standard deviation of the average of $31.14 \mathrm{t} / \mathrm{ha}$ with absolute sampling error of $9.34 \mathrm{t} / \mathrm{ha}$, when analyzed in percentage of $5.38 \%$. For the calculation of both variables a $5 \%$ significance level was considered according to Table 3.

\section{Correlation between vegetation variables and vegetation indices}

As shown in Table 4, there is a high correlation between the independent variable basal area and the dependent variables, while there is a low correlation between the independent spectral variables NDVI and MSAVI with volume and biomass. The correlations between stand variables and vegetation indices were low, but their values were significant $(\mathrm{p}<0.05)$.

It is also observed that the correlations values between the variables of the stands (volume, biomass and basal area) and vegetation indices (MSAVI and NDVI) were very similar. The volume presented a slightly higher correlation when compared to the basal area and biomass. The variable basal area was highly correlated with the volume and biomass variables. Furthermore, although its correlation with vegetation indices was low significant, but we decided to use this variable in combination with vegetation indices to generate regression models to estimate the variables of interest volume and biomass. Thus, the use of the height variable was dispensed, since obtaining the height variable in the field implies a time consuming and costly process.

The use of the basal area, which is derived from the diameter of the trees (Ponzoni et al., 2012) with a predictive variable per unit area, is justified by its high correlation with volume and biomass. In addition, this variable is intrinsically associated with the degree of utilization or growth factors and production of a given site, besides being easily determined (Husch et al., 1982).

Therefore, the combination of the variable basal area with vegetation indices related to radiation reflection by vegetation can be a viable alternative to estimate biomass 
Table 1. Statistical results of model adjustment to estimate volume and biomass per individual using the variables DBH and height.

\begin{tabular}{llllllll}
\hline Volume & \multicolumn{7}{l}{} \\
\hline Model & $\beta_{0}$ & $\beta_{1}$ & $\beta_{2}$ & $\beta_{3}$ & Syx & Syx\% & Adjusted R \\
\hline Schumacher-Hall & 0.00005 & 1.949 & 0.989 & & 0.011 & 5.020 & 0.997 \\
Meyer & 0.060 & -0.020 & 0.001 & 0.001 & 0.012 & 5.320 & 0.992 \\
Spurr & 0.004 & 0.000 & & & 0.011 & 5.070 & 0.993 \\
\hline Biomass & & & & & & & \\
\hline Model & $\beta 0$ & $\beta 1$ & $\beta 2$ & $\beta 3$ & Syx & Syx\% & Adjusted R $^{2}$ \\
\hline Schumacher-Hall & 0.013 & 2.154 & 1.006 & & 11.052 & 9.59 & 0.990 \\
Meyer & 59.986 & -16.411 & 0.828 & 0.298 & 11.198 & 9.71 & 0.978 \\
Spurr & -4.369 & 0.021 & & & 11.161 & 9.68 & 0.978 \\
\hline
\end{tabular}
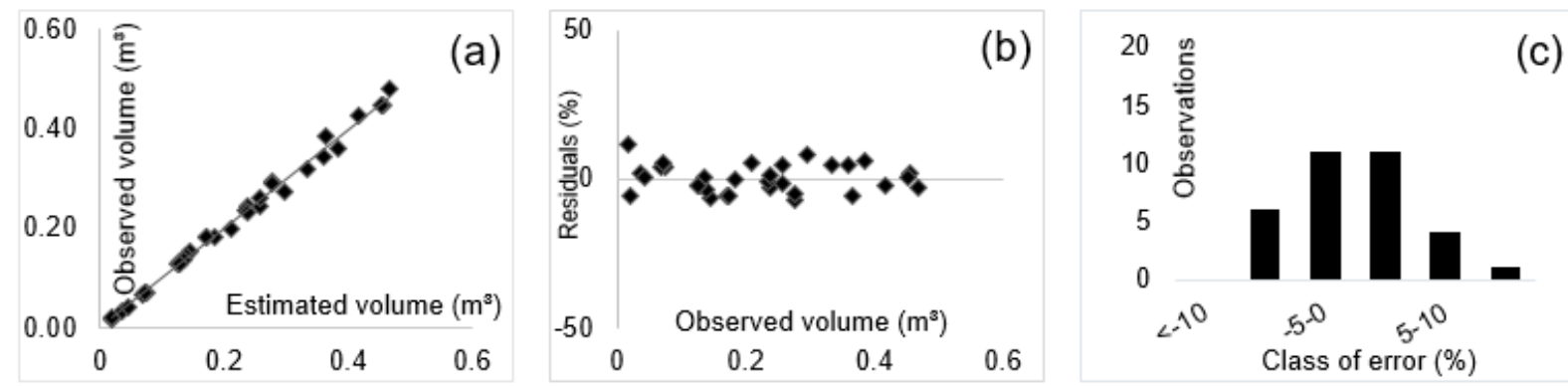

Fig 1. Dispersion of estimated value by observed value (a), dispersion of residuals (b) and distribution in error classes (c) obtained for the equation adjustments for volume estimation of the Schumacher-Hall model.

Table 2. Results obtained by the t-test of paired means applied to validate the fit of the models that estimated volume and biomass at the individual level. Performed with values of the 06 trees not used in the adjustment.

\begin{tabular}{llll|lll}
\hline \multirow{2}{*}{ Model } & \multicolumn{7}{l}{ Volume } & \multicolumn{5}{l}{ Biomass } \\
\cline { 2 - 7 } & $\mathrm{P}_{\text {calc }}$ & $\mathrm{P}_{\alpha 0.05}$ & Situation & $\mathrm{P}_{\text {calc }}$ & $\mathrm{P}_{\alpha 0.05}$ & Situation \\
\hline Schumacher-Hall & 0.38 & 0.05 & $\mathrm{~ns}$ & 0.87 & 0.05 & $\mathrm{~ns}$ \\
\hline In what: Pcalc is a value of $\mathrm{P}(\mathrm{T}<=\mathrm{t})$ bi-caudal; $\mathrm{P} \alpha$ & 0.05 is the reference value; $\mathrm{ns}$ is not significant.
\end{tabular}

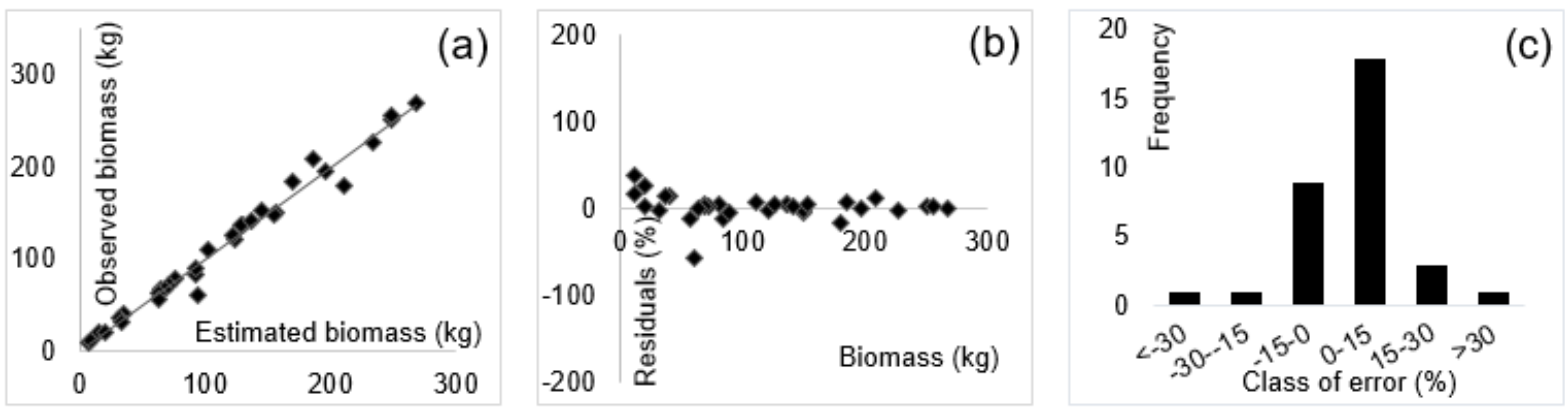

Fig 2. Dispersion of estimated value by observed value (a), dispersion of residuals (b) and distribution in error classes (c) obtained for the adjustment of equations for estimation of biomass of the Schumacher-Hall model.

Table 3. Estimates of stand parameters obtained by forest inventory using Schumacher-Hall equation adjusted for volume and biomass estimation.

\begin{tabular}{lllll}
\hline & Volume & Unit & Biomass & Unit \\
\hline Average & 330.35 & $\mathrm{~m}^{3} / \mathrm{ha}$ & 173.41 & $\mathrm{t} / \mathrm{ha}$ \\
Variance & 3289.34 & $\left(\mathrm{~m}^{3} / \mathrm{ha}\right)^{2}$ & 969.9 & $(\mathrm{t} / \mathrm{ha})^{2}$ \\
Standard deviation & 57.35 & $\mathrm{~m}^{3} / \mathrm{ha}$ & 31.14 & $\mathrm{t} / \mathrm{ha}$ \\
CV (\%) & 17.36 & $\%$ & 17.96 & $\%$ \\
Variance of the average & 72.24 & $\left(\mathrm{~m}^{3} / \mathrm{ha}\right)^{2}$ & 21.3 & $(\mathrm{t} / \mathrm{ha})^{2}$ \\
Standard error of average & 8.50 & $\mathrm{~m}^{3} / \mathrm{ha}$ & 4.62 & $\mathrm{t} / \mathrm{ha}$ \\
Absolute sample error & 17.19 & $\mathrm{~m}^{3} / \mathrm{ha}$ & 9.34 & $\mathrm{t} / \mathrm{ha}$ \\
Sample relative error & 5.20 & $\%$ & 5.38 & $\%$ \\
\hline
\end{tabular}



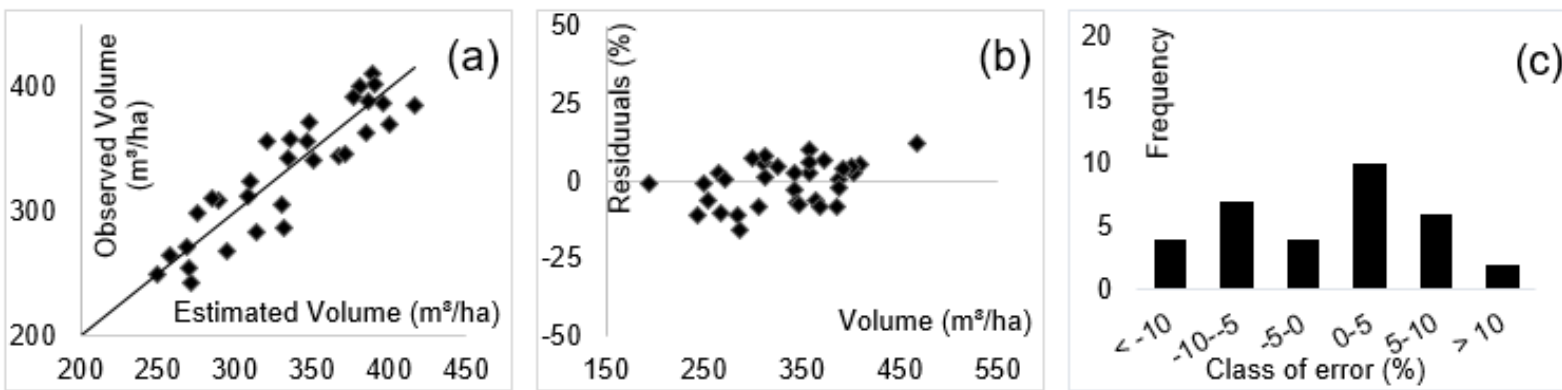

Fig 3. Dispersion of estimated value by observed value (a), dispersion of residuals (b) and distribution in error classes (c) obtained for adjustments of the Gompertz model to estimate volume in $\mathrm{m}^{3}$ per hectare $\left(\mathrm{m}^{3} / \mathrm{ha}\right)$ using vegetation indices and basal area.

Table 4. Correlation coefficients between basal area, volume, biomass and vegetation indexes.

\begin{tabular}{|c|c|c|c|c|c|}
\hline & $\begin{array}{ll}\begin{array}{l}\text { Basal } \\
\left(\mathrm{m}^{2} / \mathrm{ha}\right)\end{array} & \text { area } \\
\end{array}$ & $\begin{array}{l}\text { Biomass } \\
\text { (t/ha) }\end{array}$ & $\begin{array}{l}\text { Volume } \\
\left(\mathrm{m}^{3} / \mathrm{ha}\right)\end{array}$ & NDVI & MSAVI \\
\hline Basal area $\left(\mathrm{m}^{2} / \mathrm{ha}\right)$ & 1 & & & & \\
\hline Biomass (t/ha) & $0.977^{*}$ & 1 & & & \\
\hline Volume $\left(\mathrm{m}^{3} / \mathrm{ha}\right)$ & $0.982 *$ & $0.998 *$ & 1 & & \\
\hline NDVI & $0.35^{*}$ & $-0.32 *$ & $-0.39 *$ & 1 & \\
\hline MSAVI & $0.34^{*}$ & $0.34 *$ & $0.41^{*}$ & $0.968^{*}$ & 1 \\
\hline
\end{tabular}

* Significant at $95 \%$ probability.
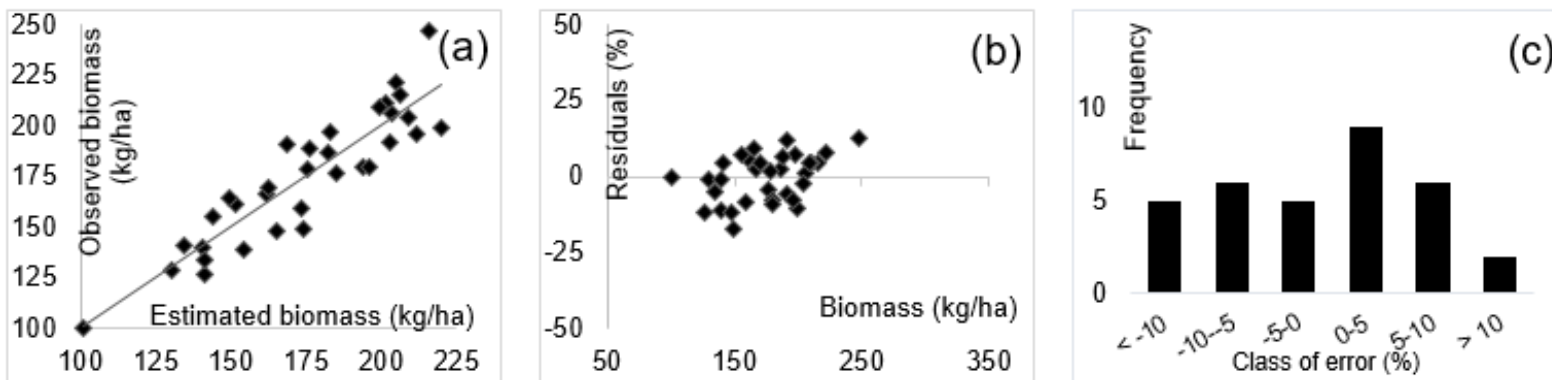

Fig 4. Dispersion of estimated value by observed value (a), dispersion of residuals (b) and distribution in error classes (c) obtained for adjustments of the Gompertz model for estimating biomass in $\mathrm{kg}$ per hectare $(\mathrm{kg} / \mathrm{ha})$ using vegetation indices.

Table 5. Statistical results of model adjustment to estimate volume $\left(\mathrm{m}^{3} / \mathrm{ha}\right)$ and biomass $(\mathrm{kg} / \mathrm{ha})$ from vegetation indices (MSAVI and NDVI).

\begin{tabular}{lllllll}
\hline Volume & \multicolumn{7}{l}{} \\
\hline Model & $\alpha$ & $\beta$ & $\gamma$ & $\mathrm{R}^{2}$ adjusted & Syx $\left(\mathrm{m}^{3} / \mathrm{ha}\right)$ & Syx $(\%)$ \\
\hline Ratkowsky & 455.8 & 0.9588 & 0.0066 & 0.916 & 24.69 & 7.44 \\
Gompertz & 482.17 & 0.3951 & 0.0047 & 0.916 & 24.67 & 7.43 \\
Logistic & 1055.5 & 873.75 & -0.718 & 0.915 & 24.73 & 7.45 \\
\hline Biomass & & & & & & \\
\hline Model & $\alpha$ & $\beta$ & $\gamma$ & $\mathrm{R}^{2}$ adjusted & Syx (kg/ha) & Syx (\%) \\
\hline Ratkowsky & 241.66 & 1.002 & 0.0067 & 0.907 & 14.10 & 8.08 \\
Gompertz & 256.26 & 0.4226 & 0.0047 & 0.907 & 14.10 & 8.08 \\
Logistic & 558.86 & 863.67 & -0.736 & 0.906 & 14.14 & 8.10
\end{tabular}

Where $\mathrm{R}^{2}$ is the coefficient of determination; Syx is the standard error of the estimate; Syx\% is the standard error of the estimate in percentage and $\alpha, \beta$ and $\gamma$ are the adjusted coefficients of the models.

Table 6. Results obtained by the t-test of paired means applied for validation of adjustment of models that estimated volume and biomass level of settlement. Done with the 07 parcels not used in the adjustment.

\begin{tabular}{|c|c|c|c|c|c|c|}
\hline \multirow{2}{*}{ Model } & \multicolumn{3}{|l|}{ Volume } & \multicolumn{3}{|l|}{ Biomass } \\
\hline & $P_{\text {calc }}$ & $P_{\alpha 95 \%}$ & Situation & $P_{\text {calc }}$ & $P_{\alpha 95 \%}$ & Situation \\
\hline Ratkowsky & 0.42 & 0.05 & ns & 0.3 & 0.05 & ns \\
\hline Gompertz & 0.45 & 0.05 & ns & 0.32 & 0.05 & ns \\
\hline Logistic & 0.50 & 0.05 & ns & 0.35 & 0.05 & ns \\
\hline
\end{tabular}


Table 7. Comparative values between statistics obtained by traditional inventory and the application of the adjusted Gompertz model.

\begin{tabular}{|c|c|c|c|c|c|c|}
\hline & Volume & & & Biomass & & \\
\hline & Inventory & $\begin{array}{l}\text { Gompertz } \\
\text { model }\end{array}$ & Unit & Inventory & $\begin{array}{l}\text { Gompertz } \\
\text { Model }\end{array}$ & Unit \\
\hline Average & 330.35 & 331.44 & $\mathrm{~m}^{3} / \mathrm{ha}$ & 173.41 & 174.24 & t/ha \\
\hline Variance & 3289.34 & 2717.88 & $\left(\mathrm{~m}^{3} / \mathrm{ha}\right)^{2}$ & 969.9 & 791.61 & $(\mathrm{t} / \mathrm{ha})^{2}$ \\
\hline Standard deviation & 57.35 & 52.13 & $\mathrm{~m}^{3} / \mathrm{ha}$ & 31.14 & 28.14 & t/ha \\
\hline CV (\%) & 17.36 & 15.73 & $\%$ & 17.96 & 16.15 & $\%$ \\
\hline Variance of the average & 72.24 & 59.69 & $\left(\mathrm{~m}^{3} / \mathrm{ha}\right)^{2}$ & 21.3 & 17.38 & $(\mathrm{t} / \mathrm{ha})^{2}$ \\
\hline Standard error of average & 8.50 & 7.73 & $\mathrm{~m}^{3} / \mathrm{ha}$ & 4.62 & 4.17 & t/ha \\
\hline Absolute sample error & 17.19 & 15.63 & $\mathrm{~m}^{3} / \mathrm{ha}$ & 9.34 & 8.43 & t/ha \\
\hline Sample relative error & 5.20 & 4.71 & $\%$ & 5.38 & 4.84 & $\%$ \\
\hline
\end{tabular}

Table 8. Mathematical models adjusted for volume and biomass estimation using biophysical parameters.

\begin{tabular}{lc}
\hline Autor & Model \\
\hline Meyer & $Y=\beta_{0}+\beta_{1} \cdot D b h+\beta_{2} \cdot D b h^{2}+\beta_{3} * D b h . H t+\varepsilon$ \\
Schumacher-Hall & $Y=\beta_{0} . D b h^{\beta 1} . H t^{\beta 2}+\varepsilon$ \\
Spurr & $Y=\beta_{0}+\beta_{1} . D b h^{2} . H t+\varepsilon$ \\
\hline In what $\beta$ 's are the coefficients to be adjusted; Dbh is the diameter at breast height; Ht is the total height; $\varepsilon$ is the error associated with the model.
\end{tabular}

Table 9. Adjusted models for volume and biomass estimation from remote sensing variables.

\begin{tabular}{|c|c|}
\hline Model & Equation \\
\hline Gompertz & $y=\alpha e^{-e^{\beta-\gamma x}}$ \\
\hline Ratkowsky & $y=\frac{\alpha}{\left(1+e^{\beta-\gamma x}\right)}$ \\
\hline Logistic & $y=\frac{\alpha}{\left(1+\left(\frac{x}{\beta}\right)^{\gamma}\right)}$ \\
\hline
\end{tabular}

and volume with precision, using less expensive techniques, without the need of variables difficult to obtain in the field, such as the case of height. It is also worth mentioning that the low correlation between the vegetation indices and the settlement variables is due to the spatial resolution of the image used, which was $25 \mathrm{~cm}$. Such resolution captures variations caused by shadow.

Chen et al. (2004) worked with IKONOS satellite images with different resolutions $(30 \mathrm{~m}, 10 \mathrm{~m}$ and $4 \mathrm{~m}$ ) and verified that images of higher spatial resolutions have lower correlations with vegetation due to the greater influence of shadows in their data. Thus, variations in the correlation values between vegetation indices and field variables can be a result of the spatial resolution of the images used or, according to Ponzoni (2001), the effect of the atmosphere and the soil must also be considered.

Almeida et al. (2014) used Landsat 5 TM images in the "Caatinga" area and verified that the variable basal area $\left(\mathrm{m}^{2}\right.$.ha-1) had no significant correlation with any variable derived from remote sensing.

Reis et al. (2018) used the vegetation indices MSAVI and NDVI to predict volume and observed a good correlation between these indices and the volume variable (NDVI $=0.49$ and MSAVI = 0.45). Berra et al. (2012) worked with the NDVI index for volume estimation in eucalyptus stands and obtained a high correlation between the index and the volume variable (NDVI $=0.79$ ).

The variations of the correlations between the indices and field variables may be due to the spatial resolution of the images. Ponzoni (2001), explained that it might be due to the nature of the satellite images, which are captured by a remote sensor, and can be influenced by other factors, such as atmosphere and soil.

Adjustment of models for volume and biomass estimation at stands level using vegetation indices and basal area

The three models adjusted by regression analysis for volume and biomass estimation from the combination of vegetation indices (eq.6), MSAVI and NDVI, and basal area presented satisfactory and very similar statistics (Table 5)

Berra et al. (2012) used Landsat satellite images and the NDVI vegetation index. They obtained an equation that explains $61 \%$ of the variability of the wood volume in eucalyptus species (adjusted $R^{2}=0.61$ ) and with a standard error of the estimate in percentage of $25.40 \%$. These authors also concluded that models using vegetation indices were better than those using only individual spectral bands. 
Miguel et al. (2015) used basal area and vegetation indices to estimate volume and biomass in a "Cerrado" fragment in the state of Tocatins. They obtained a $R^{2}$ of 0.96 and 0.91 for volume and biomass, respectively, as well as Syx\% of $11.92 \%$ and $22.76 \%$. Thus, this study presented Syx\% lower than those observed in above mentioned studies. This could be due to the nature of the forests that constitute the object of interest. They developed equations for native forest, which are naturally heterogeneous, while this study deals with a homogeneous forest stand.

When using the vegetation indices and basal area to estimate the volume of the independent stand of the models, all had similar statistical behavior. This same behavior was verified in the graphical distribution of the residuals (Figure 3). After evaluating the criteria of fit and precision and the graphic of residuals, we observed that all the models were very similar and applicable.

For biomass estimation, as well as in volume estimation, all models present values of similar adjustment and precision statistics as can be observed in (Table 5), with slight loss of precision. Such loss was expected, since biomass is a more complex variable to be estimated than the volume, due to the existence of density.

Regarding biomass (Figure 4), the dispersion of biomass was estimated and biomass observed from the Gompertz model, where its data was more compact around the trend line compared to the other models. In terms of distribution in error classes, the models generated different graphs among themselves, but with the similarity of having most observations in the interval $(0-10)$. In terms of residual dispersion, the three adjusted models had their residuals distributed homogeneously. The Gompertz model had its data slightly higher when compared to the other models. On the other hand, the Logistic model presented more dispersed observations. Subsequently, the validation of the best model adjustments for the volume and biomass was performed by the " $t$ " test for paired data, where the estimates of the 07 control plots were not used in the adjustment of the applied models. The results showed that all models presented a $\mathrm{P}(\mathrm{T}<=\mathrm{t})$ value greater than 0.05 (Table 6). Therefore, there is no statistical differences between the values predicted by the models, with the values estimated by the traditional models.

All the adjustment and precision criteria presented satisfactory results, and the equations did not present skewed errors when validated by the " $t$ " Test. Therefore, we concluded that all of them can be used. However, due to its wide application in several studies involving modeling in forest stands (Sarmento et al., 2006, Machado and Calegario, 2007; Santos et al., 2017), the equation derived from the Gompertz model was selected for estimates of the volume and biomass for subsequent comparison with the forest inventory at stand level.

Comparison between estimates of volume and biomass obtained by traditional forest inventory with the results of the estimates derived from remote sensing with basal area

Based on Gompertz model we used the combination of the vegetation indexes with the basal area for volume and biomass estimation when used for the 40 demarcated plots in the field. Then, we calculated the estimators and inventory statistics. An average volume of $331.44 \mathrm{~m}^{3}$.ha-1 and a relative sample error of $4.71 \%$ and average biomass of 174.24 t.ha $^{-1}$ and a relative sample error of $4.84 \%$ (Table 7) were obtained. On the other hand, analysis of estimators and statistics from the traditional inventory showed the averages of $330.35 \mathrm{~m}^{3}$.ha-1 and 173.41 tons. ha-1 $^{-1}$ for volume and biomass, respectively, with percentage sample errors of $5.20 \%$ and $5.38 \%$ (Table 7 ).

The statistics show the use of vegetation indices associated with field information, which can be used with precision in the estimation of biophysical parameters of forest stand. Processing of traditional inventory and the inventory with information derived from aerial images associated with the basal area have shown averages per unit area. We observed the following for the volume $\left(330.35 \mathrm{~m}^{3} /\right.$ ha and $331.44 \mathrm{~m}^{3}$ / ha, respectively), and biomass (173.41 t / ha, $174.24 \mathrm{t} / \mathrm{ha}$, respectively), with error rates of $\pm 5.20 \%$ and $4.71 \%$ for volume, and for biomass errors $\pm 5.38 \%$ and $4.84 \%$, respectively (Table 7 ). It is worth mentioning that for the estimates of volume and biomass per unit area, using the combination of vegetation indices with basal area, a slight decrease in the sampling error of the inventory, as well as the absence of the height variable were observed. These results are of great value, since they allow the direct estimation of field variables per unit area, and consequently less costs. However, the application of the technique will be valid if there is initial data collection from the field, since estimates of biophysical parameters of forests using vegetation indices are based on the knowledge of the area of study with its intrinsic characteristics. This care is due to the fact that although plantations of the genus Eucalyptus sp. may be similar in their biophysical variables, the spectral behavior may be very different because of the inherent properties of the species, making the remote sensing of forest canopy a complex activity (Galeana-Pizaña et al., 2014; Reis et al., 2018). Thus, the addition of field variables, such as the basal area, which presents high correction with production data (Husch et al., 1982) in the models, guarantees improvements in the estimators and consequently more accurate estimates.

\section{Materials and methods}

\section{Plant materials}

The plant material used was clones of Eucalyptus urophylla S. T. Blake $x$ Eucalyptus grandis Hill ex-Maiden with seven years of age set in a $3 \mathrm{~m} \times 2 \mathrm{~m}$ spacing.

\section{Study area}

The study was conducted in Brasília, Brazil. The stand occupied a total area of 25 hectares and the soil that predominates in the region is the type Red-Yellow Latosol, low in nutrients and high in aluminum (EMBRAPA, 2013). In terms of climate, the site is classified as Aw, according to Köppen classification, with maximum temperature of $28.5^{\circ} \mathrm{C}$ and minimum $12^{\circ} \mathrm{C}$, average annual precipitation of 1,600 $\mathrm{mm}$ (Fiedler et al., 2004).

\section{Methodology}

The work was divided into two stages. The first stage involved the forest inventory of the stand, the cubage of the 
selected trees and the selection of samples (leaves, stem and branches) of these trees for quantification of biomass. The second step consisted of obtaining data derived from remote sensing, from which adjusting equations for volume and biomass estimation was done. Sequentially, the data obtained from the traditional inventory were used to validate the estimates made from the data derived from the images.

\section{Forest inventory}

The forest inventory of the stands was based on the random allocation of 40 sampling units with dimensions $10 \mathrm{~m} \times 10 \mathrm{~m}$ $\left(100 \mathrm{~m}^{2}\right)$. In each plot, the DBH (diameter at breast height of $1.30 \mathrm{~m}$ from the ground) was measured from all living trees using dendrometric tape. The inclusion criterion was $\mathrm{DBH} \geq$ $5.00 \mathrm{~cm}$. The total height $(\mathrm{Ht})$ of the trees was also measured using a Suunto hypsometer. Trees were sequentially enumerated in each plot using aluminum tags, totaling 569 sampled trees. The population parameter estimates were calculated according to Pellico Netto; Brena, 1997.

\section{Cubage}

For rigorous cubing, 39 trees belonging to different classes of diameters were selected in an area close to the sample units. These were felled at $10 \mathrm{~cm}$ from the ground using chainsaws, and their initial diameter measured at this point. The diameters of the subsequent sections were measured at $0.50 \mathrm{~m}, 1.30 \mathrm{~m}$, thereafter 1 by 1 meter until the tip. Using the Smalian method, the volume of each section was calculated by the arithmetic mean of the sectional areas of its ends by their length. To calculate the tip volume, $1 / 3$ of the area of the last section was used for the sections according to equation 1 :

$$
\text { Eq. (1) Vsection }=\frac{g_{n}+g_{n+1}}{2} * L
$$

Where: Vsection is the volume of the section; gn is the area of section $n$; gn +1 is the area of section $n+1$; $L$ is the length of the section.

\section{Quantification of biomass}

All the cubed trees were sectioned and their compartments (leaves, stem and branches) weighed separately with an electronic platform scale with capacity for $300 \mathrm{~kg}$ with a precision of $\pm 0.5 \mathrm{~kg}$. Samples of the compartments of all the trees with variable mass of 50 to $300 \mathrm{~g}$ were collected and taken to the laboratory. Their green mass was measured with an analytical balance with a precision of $0.01 \mathrm{~g}$. Afterwards, they were submitted to a constant temperature of $103 \pm 2^{\circ} \mathrm{C}$ for the woody material and $75 \pm 2^{\circ} \mathrm{C}$ for the leaves (Smith, 1954), until reaching the constant weight for later determination of the dry mass.

The relationship coefficient for biomass estimation was calculated (Soares et al., 2006), according to equation 2:

$$
\text { Eq. (2) } \quad \mathrm{Cr}=\frac{\mathrm{M}_{\mathrm{s}}}{\mathrm{M}_{\mathrm{u}}}
$$

Where $\mathrm{Cr}=$ ratio coefficient; $\mathrm{Ms}=$ dry mass (g or $\mathrm{kg}$ ); $\mathrm{Mu}=$ wet mass (g or $\mathrm{kg}$ ).
The coefficient generated was used to estimate the dry biomass of all the trees that were sectioned and had their compartments weighed in the field, using equation 3 :

$$
\text { Eq. (3) } \quad \mathrm{Bo}_{\mathrm{c}}=\mathrm{c}_{\mathrm{r}} * \mathrm{P}_{\mathrm{uc}}
$$

Where $\mathrm{Bo}_{\mathrm{c}}=$ dry biomass compartment (kg or ton); $\mathrm{Cr}=$ ratio coefficient; $\mathrm{Puc}=$ wet weight compartment ( $\mathrm{kg}$ or ton).

\section{Determination of vegetation indices}

The determination of vegetation indices was done from an aerial image provided by the Federal District Development Agency (TERRACAP), obtained in 2017 with an Ultracam XP camera that has spatial resolution of $25 \mathrm{~cm}$, as well as 3 bands in the visible and 1 in the near infrared, characteristic that guided the choice of the vegetation indices. The vegetation indices calculated were the Modified SoilAdjusted Vegetation Index (MSAVI) (Qi et al., 1994) and Normalized Difference Vegetation Index (NDVI) (Rouse et al., 1974) and their formulas as below:

$$
\begin{aligned}
& \text { Eq. (4) } \quad M S A V I=\frac{(\text { Nir-Red }) *(1+L)}{(\text { Nir }+ \text { Red }+L)} \\
& \text { Eq. (5) } \quad N D V I=\frac{\text { Nir-Red }}{\text { Nir }+ \text { Red }}
\end{aligned}
$$

Where, Nir is the near-infrared pixel (band 4); Red is the pixel where the reflectance occurs in red (band 3 ) and $L$ is the correction factor of the brightness of the soil, for which it was adopted 1.2, standard followed by et al. (1994).

\section{Conventional estimation of volume and biomass}

Based on the forest inventory data, cubage and biomass quantification, three statistical regression models were adjusted to estimate the volume and biomass of individual trees (Table 8). Out of 39 cubed trees, 33 were randomly selected and used for adjustments. The others were used for validation.

\section{Volume and biomass estimation using vegetation indices}

From the forest inventory data and the remote sensing variables, we proceeded with a new adjust of equations to estimate volume and biomass per unit area. After attempts and combination of several vegetation indices, we reached the best result, whose independent variable was calculated by: Eq. (6) $\quad x=$ G.MSAVI.NDVI

Where, $\mathrm{x}$ is the independent variable; $\mathrm{G}$ is the basal area in $\mathrm{m}^{2}$ / ha; MSAVI and NDVI are the average vegetation indices of each plot/hectare. The models used in the adjustment are set out in Table 9.

For the adjustment of the models, the data of 33 plots were used. The other 7 plots were used to validate the adjusted models. Once the models were selected and the volume and the biomass of the plot were estimated, the estimates from the traditional forest inventory were compared with the estimates that used the vegetation index and basal area.

\section{Selecting models and statistical analysis}

The selection of the best adjusted models for volume and biomass estimation was based on the analysis of the adjusted coefficient of determination ( $R^{2}$ adjusted), standard error of the estimate in percentage (Syx\%) and residual distribution, calculated by the difference between the 
observed value (volume or biomass) and the estimated value (Draper and Smith, 1998).

For the adjustment of the models, the data of 33 plots were used. The remaining 7 plots were used to validate the adjusted models, based on the " $t$ " test of paired means ( $p$ $<0.05)$.

Once the models were selected and the volume and biomass of the plot were estimated, the estimates from the traditional forest inventory were compared with the estimates that used the vegetation index and basal area.

The " $P$ " value was used to evaluate the existence of a significant difference between the volume and biomass estimates using remote sensing information and using traditional inventory data.

\section{Conclusions}

Of the models used for estimating volume and individual biomass, the Schumacher-Hall equation is the recommended one. For the models adjusted per unit area, involving the combination of vegetation indices with the basal area, the originating equation from the Gompertz model is recommended. The adjustment of models that used the combination of vegetation indices with basal area was accurate and presented results as good as those generated by the traditional forest inventory. However, its application requires previous field data collection. Nevertheless, when adjusted, this procedure is more agile, and therefore less costly, since it is not necessary to obtain the variable height.

\section{Acknowledgments}

The authors are thankful for the support of the University of Brasilia and the National Council for Scientific and Technological Development (CNPq).

\section{References}

Almeida AQ, Mello AA, Dória Neto ALN, Ferraz R C (2014) Relações empíricas entre características dendrométricas da Caatinga brasileira e dados TM Landsat5. Pesquisa Agropecuária Brasileira, Brasília. 49:306-315.

Berra EF, Brandelero C, Pereira RS, Sebem E, de Godoy Goergen LC, Benedetti ACP, Lippert DB (2012) Estimativa do volume total de madeira em espécies de eucalipto a partir de imagens de satélite Landsat. Ciência Florestal. 22(4), 853-864.

Chen X, Vierling L, Rowell E, DeFelice T (2004) Using lidar and effective LAI data to evaluate IKONOS and Landsat 7 ETM+ vegetation cover estimates in a ponderosa pine forest. Remote Sensing of Environment. 91(1), 14-26.

Castro RVO, Soares CPB, Leite HG, Souza AL, Nogueira GS, Martins FB (2013) Individual growth model for Eucalyptus stands in Brazil using artificial neural network. ISRN Forestry. 1-13.

Cecília RC, Mason EG, Richard W, Fernando R (2014) Ecuaciones de volumen y ahusamiento para P. taeda (L.) y E. grandis (Hill ex. Maiden). Agrociencia Uruguay. 18(2): 47-60.

Draper NR, Smith H (1981) Applied regression analysis. 3a. ed. New York: J. Wiley. 709 p.
Du H, Zeng F, Peng W, Wang K, Zhang H, Liu L, Song T (2015) Carbon storage in a Eucalyptus plantation chronosequence in Southern China. Forests. 6(06): 1763-1778.

EMBRAPA - Empresa Brasileira de Pesquisa Agropecuária (2013) Sistema Brasileiro de Classificação de Solos, 3a edição.

Ferraz Filho AC, Scolforo JRS (2014) The coppice-withstandards silvicultural system as applied to Eucalyptus plantations - a review. Journal of Forestry Research. 2:237-248.

Fiedler NC, Rezende AV, Venturoili F (2004) Efeito de incêndios florestais na estrutura e composição florística de uma área de cerrado sensu stricto na fazenda Água LimpaDF. Revista Árvore. 28(1).

Fontoura MR, Caron BO, Eloy E, Trevisan R, Trautenmüller JW, Behling A (2017) Modelos alométricos para estimativa de biomassa em área de regeneração natural de Ateleia glazioviana Baill. Floresta. 47(4):469-478.

Freitas BC, Andrade VCL De (2017) Bancos de dados de cubagem rigorosa de árvores-amostra de Corymbia citriodora empregados no ajuste de modelos volumétricos regionais. Advances in Forestry Science.93-97.

Fumes G, Demétrio CGB, Villegas C, Corrente JE, Bazzo JF 92017) Growth curves for diameter and height using mixed models: An application in eucalyptus seedling. Open J Forestry. 7(4):403-415.

Galeana-Pizaña JM, López-Caloca A, López-Quiroz P, SilvánCárdenas JL, Couturier S (2014) Modeling the spatial distribution of above-ground carbon in Mexican coniferous forests using remote sensing and a geostatistical approach. Int J Appl Earth Observ Geoinform. 30: 179-189.

Gomes FP, Garcia CH (2002) Estatística aplicada a experimentos agronômicos e florestais. Piracicaba: Fealq (11) 21.

Gonçalves JL, Alvares CA, Rocha JH, Brandani CB, Hakamada $R$ (2017) Eucalypt plantation management in regions with water stress. Southern Forests., 79(3):169-183.

Günlü A, Ercanli I, Şenyurt M, Yayla AT (2012) Modeling stand volume using Landsat TM data for fir stands (Abies bornmuelleriana Matth.) located in Buyukduz planning unit, TURKEY. Kastamonu Üniversitesi Orman Fakültesi Dergisi. 12(3), 65-71.

Hernández-Ramos J, De Los Santos-Posadas HM, ValdézLazalde JR, Tamarit-Urias JC, Ángeles-Pérez G, HernándezRamos A, Méndez-Lopez B, Peduzzi A (2017) Estimación del volumen comercial en plantaciones de eucalyptus urophylla con modelos de volumen total y de razón. Agrociencia. 51(5):561-580.

Huang S, Ramirez C, McElhaney M, Evans K (2018) F 3: Simulating spatiotemporal forest change from field inventory, remote sensing, growth modeling, and management actions. Forest Ecology and Management. 415:26-37.

Husch B, Miller CL, Beers TW (1982) Forest mensuration. 3 ed. New York: J. Willey, 402p.

Kross A, McNairn H, Lapen D, Sunohara M, Champagne C (2015) Assessment of RapidEye vegetation indices for estimation of leaf area index and biomass in corn and soybean crops. Int J Appl Earth Observ Geoinformation. 34: 235-248. 
Leyk S, Koehl M, Von Poncét F (2002) Application of future TerraSAR data for improvement of forest resource assessments. In Proceedings of the Forest-SAT 2002 Conference on Operational Tools in Forestry using Remote Sensing Techniques, August (pp. 5-9).

Machado Pires L, Calegario N (2007) Ajuste de modelos estocásticos lineares e não-lineares para a descrição do perfil longitudinal de árvores. Revista Árvore. 31(5).

Marcatti GE, Resende RT, Resende MDV, Ribeiro CAA, Dos Santos AR, Da Cruz JP, Leite HG (2017) GIS-based approach applied to optimizing recommendations of Eucalyptus genotypes. Forest ecology and management. 392:144-153.

Mendes S, Almeida R, Duarte L, Teodoro AC (2018) Remote sensing and GIS combination to evaluate the ecosystems' conditions in" Serras do Porto". In: Remote Sensing for Agriculture, Ecosystems, and Hydrology XX. International Society for Optics and Photonics.

Miguel EP, Rezende AV, Leal FA, Matricardi EAT, do Vale AT, Pereira RS (2015) Redes neurais artificiais para a modelagem do volume de madeira e biomassa do cerradão com dados de satélite. Pesquisa Agropecuária Brasileira. 50(9): 829-839.

Miura N, Jones SD (2010) Characterizing forest ecological structure using pulse types and heights of airborne laser scanning. Remote Sensing of Environment. 114(5):10691076.

Oliveira LT, Ferreira MZ, de Carvalho LMT, Ferraz Filho AC, de Andrade Oliveira TC, de Oliveira Silveira EM, Junior FWA (2014) Determinação do volume de madeira em povoamento de eucalipto por escâner a laser aerotransportado. Pesquisa Agropecuária Brasileira. 49(9): 692-699.

Paes FASV, Lima AMN, Hakamada RE, Barros NF (2013) Impacto do Manejo dos Resíduos da Colheita, do Preparo do solo e da Adubação na Produtividade de Eucalipto. Revista Brasileira de Ciência de Solo, Viçosa. 37:1081-1090.

Pan Y, Birdsey RA, Phillips OL, Jackson RB (2013) The structure, distribution, and Biomass of the world's forests. Annual Review of Ecology, Evolution, and Systematics. 44(1):593-622.

Pasher J, King DJ (2010) Multivariate forest structure modelling and mapping using high resolution airborne imagery and topographic information. Remote Sensing of Environment. 114(8):1718-1732.

Pelissari AL, Lanssanova LR, Drescher R (2011) Modelos volumétricos para Pinus tropicais, em povoamento homogêneo, no Estado de Rondônia. Pesquisa Florestal Brasileira. 67:173-181.

Péllico Netto S, Brena D (1997) Inventário Florestal. v 1. Curitiba: editorado.

Ponzoni FJ, Shimabukuro Y, Kuplich TM (2012) Sensoriamento Remoto no Estudo da Vegetação, 2nd ed., Editora Oficina de Textos: São Paulo, Brasil, p. 164.

Ponzoni FJ (2001) Comportamento espectral da vegetação. Sensoriamento remoto: reflectância de alvos naturais, 1: 157-199.

Qi J, Chehbouni A, Huete AR, Kerr YH, Sorooshian S (1994) A modified soil adjusted vegetation index. Remote Sensing of Environment 48(2):119-126.
Reis AA, Carvalho MC, de Mello JM, Gomide LR, Ferraz Filho AC, Junior FWA (2018) Spatial prediction of basal area and volume in Eucalyptus stands using Landsat TM data: an assessment of prediction methods. New Zealand Journal of Forestry Science. 48(1):1.

Ribeiro SC, Soares CPB, Fehrmann L, Jacovine LAG, Von Gadow K (2015) Aboveground and belowground biomass and carbon estimates for clonal Eucalyptus trees in Southeast Brazil. Revista Árvore. 39(2):353-363.

Rouse Jr J, Haas RH, Schell JA, Deering DW (1974) Monitoring vegetation systems in the Great Plains with ERTS.

Santana AC, Amin MAM, Costa NL (2017) Evaluation of nonlinear econometric models to estimate the wood volume of amazon forests. African Journal of Agricultural Research 12(6):382-388.

Santiago-García W, Pérez-López E, Quiñonez-Barraza G, Rodríguez-Ortiz G, Santiago-García E, Ruiz-Aquino F, Tamarit-Urias JCA (2017) dynamic system of growth and yield equations for Pinus patula. Forests. 8(12):465.

Santos ACA, Silva S, Leite HG, da Cruz JP (2017) Influence of soil and climate variability in the growth of eucalyptus clones in Bahia Northeast. Pesquisa Florestal Brasileira. 37(91):259-268.

Sarmento JLR, Regazzi AJ, Sousa WD, Torres RDA, Breda FC, Menezes GDO (2006) Estudo da curva de crescimento de ovinos Santa Inês. Revista Brasileira de Zootecnia. 35(2): 435-442.

Smith DM (1954) Maximum Moisture Content Method for Determining Specific Gravity of Small Wood Samples. U.S. Forest Products Laboratory Report. no 2014, 8 p.

Soares C, Neto FP, Souza A (2006) Dendrometria e inventário florestal: 1-276. Editora UFV, Viçosa.

Souza TDS, Ramalho MAP, De Lima BM, Rezende GDSP (2017) Performance of Eucalyptus clones according to environmental conditions. Scientia Forestalis. 45(116): 601-610.

Tewari VP, Singh B (2018) Total Wood Volume Equations for Tectona Grandis Linn F. Stands in Gujarat, India. Journal of Forest and Environmental Science. 34(4):313-320.

Timothy D, Onisimo M, Cletah S, Samuel A, Bangira T (2016) Remote sensing aboveground forest biomass: A review. Tropical Ecology. Varanasi. 57:125-132.

Vrieling A, Meroni M, Darvishzadeh R, Skidmore AK, Wang T, Zurita-Milla R, Paganini M (2018) Vegetation phenology from Sentinel-2 and field cameras for a Dutch barrier island. Remote Sensing of Environment.

White JC, Coops NC, Wulder MA, Vastaranta M, Hilker T, Tompalski P (2016) Remote sensing technologies for enhancing forest inventories: A review. Canadian Journal of Remote Sensing. 42(5):619-641.

Zhang Z, Liu M, Liu X, Zhou GA (2018) new vegetation index based on multitemporal Sentinel-2 images for discriminating heavy metal stress levels in rice. Sensors. 18(7):2172. 